\title{
NOTES ON ZEBRAS
}

THE CAPE MOUNTAIN ZEBRA (EQUUS ZEBRA ZEBRA)

\author{
By R. Brgalke
}

Director of the National Zoological Gardens, Pretoria

1. The Mountain Zebra National Park.-The Mountain Zebra National Park was established with six Cape Mountain Zebras (only one of these a mare) on the 2nd July, 1937, by Proclamation No. 112 of 1937.

The following table, compiled from the annual reports of the National Parks Board of Trustees, indicates the status of the Cape Mountain Zebra in the Mountain Zebra National Park during the years 1937 to 1949 :-

\begin{tabular}{|c|c|c|c|}
\hline Year. & & $\begin{array}{c}\text { No. of } \\
\text { Stallions. }\end{array}$ & $\begin{array}{l}\text { No. of } \\
\text { Mares. }\end{array}$ \\
\hline 1987 & . & . 5 & 1 \\
\hline 1938 & . & 5 & $\overline{1}$ \\
\hline 1939 & . & 5 & $\overline{\mathbf{2}}$ \\
\hline $\mathbf{1 9 4 0}$ & . & 5 & $\overrightarrow{\mathbf{1}}$ \\
\hline 1941 & . & . & $\mathrm{I}$ \\
\hline 1942 & . & 4 & $\hat{\mathbf{1}}$ \\
\hline 1943 & . & 4 & i \\
\hline 1944 & . & $\mathbf{3}$ & $\overline{\mathbf{I}}$ \\
\hline 1945 & . & $\mathbf{2}$ & 1 \\
\hline 1946 & . & . & 1 \\
\hline 1947 & . & . & 0 \\
\hline 1948 & . & . & 0 \\
\hline 1949 & . &. & 0 \\
\hline
\end{tabular}

The remaining two stallions were destroyed on the 22nd August, 1950, and handed over to the Transvaal Museum, in Pretoria, where they are incorporated in the collection under the numbers T.M. 10200 and T.M. 10201.

On the 9th November, 1950, a total of eleven Cape Mountain Zebras (number of mares unknown) presented to the National Parks Board of Trustees by Mr. H. J. Lombard, of the farm Waterval, were successfully transferred to the Mountain Zebra National Park. A new start has, therefore, been made with the preservation of this animal in the Mountain Zebra National Park.

2. Survey of the Status of the Cape Mountain Zebra.-At the request of the Scientific Advisory Council for National Parks and Nature Reserves, Professor R. H. Compton and I undertook a survey of the status of the Cape Mountain Zebra in December, 1949. The following is an extract from our report dated 7th February, 1950 :-

"Information about the exact number of Cape Mountain 
Zebras surviving in the Union is unfortunately not available. The numbers appear to be as follows :-

(a) Mountain Zebra National Park (1949) • • • . 2 (stallions)

(b) Mr. N. D. C. Michau's farm Doornhoek in the Division of Cradock (December, 1949)

(c) Mr. H. Lombard's farm Waterval in the Division of Cradock (December, 1949)

(d) Along the northern slopes of the Outeniquas Mountains and on adjacent farms . . . (approx.)

(e) Kamanassie Area . . . . . . (approx.) 15

Totax . (approx.) $\overline{69-74}$

In addition to the above, there may be a few specimens on other farms along the northern slopes of the Outeniquas Mountains."

3. Zebras for Mail Coaches.--Towards the end of the nineteenth century Mr. D. Zeederberg tried zebras in his mail coaches with the object of eliminating losses from horse sickness. He had to abandon the attempt, however, because he found the zebras (presumably $E$. burchellii transvaalensis from the northern Transvaal) unsuitable as draft animals.

\section{OTHER ZEBRAS}

\section{By T. J. SteYN}

Although scattered and greatly reduced in numbers, Hartmann's Zebras (form(s) of Mountain Zebra) still seem to occur over practically the whole mountainous coastal region of SouthWest Africa, west of the Namib, from the Orange River in the south to beyond the Cunene in the north.

Different forms of Burchell's Zebra are to be found in northern South-West Africa (Kaokoveld, Ovamboland, the Namutoni Reserve, the Kungveld, and the Caprivi Zipfel), Northern Bechuanaland, Northern and Eastern Transvaal, and in the reserves of Zululand.

No Grevy's Zebra occur within the Union, South-West Africa, or Bechuanaland. 